\title{
ANALISIS PENGARUH NILAI IPM DAN JUMLAH PENDUDUK TERHADAP TIMBUNAN SAMPAH DI TPA SE-PROVINSI KEPULAUAN BANGKA BELITUNG: SEBUAH STUDI PENDAHULUAN
}

\author{
M. Denny Elyasa \\ Sekretariat Daerah Provinsi Kepulauan Bangka Belitung \\ Kompleks Kantor Gubernur Kepulauan Bangka Belitung Jl. Air Itam Pangkalpinang, 33149 \\ Indonesia,E-mail: dennybabel12@gmail.com
}

\begin{abstract}
Abstrak
Kajian ini bertujuan untuk mengetahui sejauh mana nilai IPM mempengaruhi jumlah sampah timbunan di Tempat Pembuangan Sampah (TPA) yang terdapat di tiap-tiap kabupaten/kota se-Provinsi Kepulauan Bangka Belitung. Data yang digunakan merupakan data sekunder yang didapat dari Biro Pusat Statistik (BPS) Provinsi Kepulauan Bangka Belitung dan Data dari Kantor Kementerian Lingkungan Hidup dan Kehutanan. Metode penelitian bersifat kuantitatif deskritif dengan menggunakan regresi sederhana dan metode rasio. Dari hasil pengujian didapat bahwa semakin tinggi nilai IPM suatu daerah semakin tinggi pula timbunan sampah di TPA daerah tersebut, artinya nilai IPM yang tinggi tidak memberikan korelasi positif terhadap penurunan timbunan sampah yang ada di TPA. Selain itu didapat pula bahwa besarnya jumlah penduduk di satu daerah di Provinsi Kepulauan Bangka Belitung belum tentu menyebabkan timbunan sampah di TPA daerah tersebut tinggi. Kajian ini merekomendasikan pentingnya untuk memasukkan indikator kebersihan ke dalam IPM.
\end{abstract}

Kata kunci: Standar hidup layak, Lingkungan, Bangka Belitung

\begin{abstract}
This study aims to determine to which extent the HDI value affects the amount of waste dumped in landfills (TPA) found in each regency / city throughout the Province of the Bangka Belitung Islands. In The data used is secondary data obtained from the Central Bureau of Statistics (BPS) of the Bangka Belitung Islands Province and Data from the Ministry of Environment and Forestry. The research method is quantitative descriptive by using simple regression and ratio technique. From the test results it was found that the higher the value of HDI is the higher the amount of the waste dumped in the landfill in a region, meaning that high HDI values did not provide a positive correlation to landfill in the landfill. In addition, it was found that the size of the population in one area in the Bangka Belitung Islands Province do not always cause the high in the waste in the landfill. This study recommends the importance of improving the HDI by adding cleaness indicator into the equation index.
\end{abstract}

Keywords: Decent living standards, environment, Bangka Belitung 


\section{PENDAHULUAN}

Untuk meningkatkan kualitas hidup masyarakat di masa kini dan masa akan datang perlu kiranya didukung kondisi dan lingkungan masyarakat yang sehat. Lingkungan yang sehat adalah seberapa baiknya pengelolaan sampah yang ada. Sampah telah menjadi isu besar tidak hanya di Indoensia tapi juga di dunia. Bahkan Indonesia menjadi penyumbang sampah plastik no.2 di dunia (Sherly Puspita.2018). Diperkotaan sampah menjadi masalah utama lingkungan, berkembangnya suatu kota dikarenakan makin tingginya tingkat pertumbuhan ekonomi menyebabkan tingginya tingkat urbanisasi.

Menurut Fitri Rahmadani Harahap (2013) karena tidak ada pengendalian di dalamnya menyebabkan urbanisasi menimbulkan berbagai macam masalah. Hampir semua negara mengalami masalah urbanisasi, termasuk Indonesia pun mengalami masalah. Akibat membengkaknya jumlah penduduk diperkotaan, meningkatkan konsumsi masyarakat diperkotaan, hal ini mengakibatkan jumlah sampah juga meningkat. Tanpa pengelolaan sampah yang baik maka akan menyebabkan kerusakan dan pencemaran lingkungan.
Menurut Biro Pusat Statistik Indeks Pembangunan Manusia (IPM) merupakan cara untuk melihat bagaimana penduduk dapat mengakses hasil pembangunan dalam memperoleh pendapatan, kesehatan, pendidikan, dan sebagainya. IPM dibentuk oleh 3 (tiga) dimensi dasar,yaitu umur panjang dan hidup sehat, Pengetahuan, dan Standar hidup layak. IPM adalah indikator penting yang diperkenalkan oleh UNDP pada tahun 1990 untuk mengukur keberhasilan dalam upaya membangun kualitas hidup manusia (masyarakat/penduduk). Diharapkan dengan semakin baiknya nilai IPM akan meningkatkan pemahaman tentang pengelolaan sampah dan hal tersebut akan mempengaruhi jumlah timbunansampah di TPA. Rifka Charisa Devi (2016) menyimpulkan bahwa rendahnya pendidikan tidak berarti pemahaman sampah masyarakat kurang, tapi ada faktor lain yang menyebabkan pemahaman masyarakat tinggi.

Dalam kajian ini masalah hanya dibatasi oleh hubungan IPM dengan jumlah sampah ditimbun di TPA dan jumlah penduduk dengan jumlah sampah ditimbun di TPA. Apabila ada hal lainnya tidak menutup kemungkinan kajian ini untuk lebih didalami. 


\section{METODE PENELITIAN}

Metode penelitian ini bersifat kuantitatif deskritif adapun data diperoleh dari Biro Pusat Statistik dan Sistem Informasi Pengolahan Sampah Nasional yang dimiliki oleh Kementerian Lingkungan Hidup dan Kehutanan Republik Indonesia. Untuk mengumpulkan data digunakan adalah metode studi pustaka yang terdiri atas pencarian data dan informasi melalui dokumen-dokumen pendukung berupa data dari statistik dari lembaga resmi pemerintah, jurnal ilmiah, dan dokumen dari internet.

Untuk memperkuat hasil kajian digunakan uji statistik regresi sederhana menggunakan excel (Junaidi.2014) dan metode rasio terhadap data - data yang tidak bisa diolah dengan regresi.

\section{HASIL DAN PEMBAHASAN}

Perilaku yang buruk seringkali menyebabkan bencana yang menyebabkan tersumbatnya drainase karena sampah seperti banjir. Masalah sampah di suatu kawasan dapat meliputi tingginya laju timbunan sampah dan kepedulian masyarakat yang masih rendah (Hardiatmi, 2011).

Meningkatnya nilai Indeks Pembangunan Manusia (IPM) berarti meningkatnya 3 (tiga) dimensi dasar,yaitu : umur panjang dan hidup sehat, pengetahuan, serta standar hidup layak dimana salah satu indikatornya adalah angka harapan sekolah dan naiknya PDRB suatu daerah. Maka secara logika semakin tingginya IPM maka tingkat kesadaran masyarakat akan pengeloaan sampah semakin bertambah. Berkurangnya sampah dari lingkungan masyarakat berarti akan mengurangi jumlah sampah yang akan dibawa ke TPA. Untuk itu kajian ini dibuat untuk menguji hipotesis yang ada. 
Tabel 1. Perbandingan IPM dengan Jumlah Sampah di TPA

\begin{tabular}{|l|r|r|}
\hline \multirow{2}{*}{ Kab/Kota } & IPM & \multicolumn{2}{|l|}{$\begin{array}{l}\text { Jumlah Sampah } \\
\text { Ditimbun }\end{array}$} \\
& & TPA \\
& (Ton/Hari) \\
\hline & 71,09 & 2017-2018 \\
\hline Bangka & 70,93 & 25,15 \\
\hline Belitung & 67,94 & 35,36 \\
\hline Bangka Barat & 68,99 & 8,26 \\
\hline Bangka Tengah & 65,02 & 13,5 \\
\hline Bangka Selatan & 69,57 & 11,59 \\
\hline Belitung Timur & 76,86 & 27,69 \\
\hline Pangkalpinang & & 120 \\
\hline
\end{tabular}

Tabel di atas menggambarkan seberapa pengaruh antara jumlah penduduk, IPM dengan jumlah sampah ditimbun di TPA.

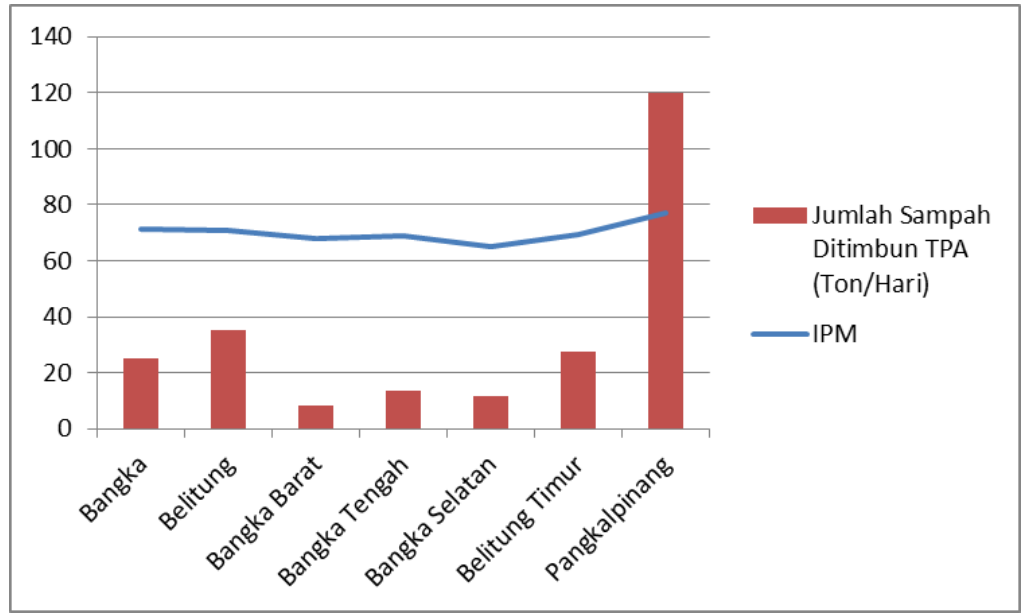

Gambar 1. Pengaruh tingginya IPM terhadap jumlah sampah yang ditimbun di TPA. 


\begin{tabular}{|l|r|}
\hline SUMMARY OUTPUT \\
\hline \multicolumn{2}{|c|}{ Regression Statistics } \\
\hline Multiple R & 0,90556438 \\
\hline R Square & 0,82004684 \\
\hline Adjusted R Square & 0,78405621 \\
\hline Standard Error & 1,68980812 \\
\hline Observations & 7 \\
\hline
\end{tabular}

Gambar 2. Hasil Perhitungan $R$ Square.

Dari hasil perhitungan didapat $\mathrm{R}$

Square sebesar 0,82, hal ini menunjukkan bahwa pengaruh IPM terhadap jumlah sampah yang ditimbun

\begin{tabular}{|l|r|c|c|c|c|}
\hline ANOVA & & & & & \\
\hline & $d f$ & $S S$ & MS & $F$ & Significance $F$ \\
\hline Regression & 1 & 65,06148547 & 65,06148547 & 22,78501 & 0,004999894 \\
\hline Residual & 5 & 14,27725739 & 2,855451478 & & \\
\hline Total & 6 & 79,33874286 & & & \\
\hline
\end{tabular}

Gambar 3. Hasil Perhitungan Sig.

Berdasarkan output di atas semakin tingginya nilai IPM akan diketahui nilai signifikansi (sig.) sebesar menurunkan jumlah timbunan sampah 0,004 lebih kecil dari < probabilitas 0,05 ternyata untuk kasus ini tidak tepat. Hal yang menunjukkan ada pengaruh nilai IPM dengan jumlah sampah yang ditimbun di TPA. Hal ini menunjukkan bahwa semangkin besar nilai IPM menunjukkan semakin tingginya jumlah sampah yang ditimbun di TPA. ini mungkin disebabkan salah satu faktornya adalah makin meningkatnya pendapatan masyakarat, yang menyebabkan konsumsi masyarakat meningkat.

Hoornweg dan Bhada-Tata (2012) menyebutkan bahwa beberapa

Tingginya nilai IPM yang berbanding lurus dengan tingginya timbunan sampah di TPA ternyata membalikkan asumsi selama ini di mana teori mengaitkan langsung antara tingkat pendapatan dari suatu negara dengan jumlah sampah yang mereka hasilkan. Negara-negara yang tingkat pendapatan 
rendah akan menghasilkan sampah yang lebih sedikit daripada negara dengan pendapatan tinggi. Hal ini menunjukkan meningkatnya pendapatan daerah berarti meningkatnya standar hidup layak, dengan meningkatnya standar hidup layak berarti meningkatkan konsumsi masyakarat. Sesuai dengan tipologi daerah menurut penelitian Gita Prajati, Tri Padmi, dan Benno Rahardyan (2015). Namun, hal ini perlu penelitian lebih lanjut untuk lebih memperjelas faktor - faktor penyebabnya.

Apabila Meningkatnya IPM suatu daerah mempengaruhi jumlah sampah ditimbun di TPA, hal tersebut berbeda dengan perbandingan antara besaran jumlah penduduk dengan tingginya timbunan sampah di TPA. Dimana tingginya jumlah penduduk ternyata tidak mempengaruhi volume timbunan sampah di TPA.

Tabel 2. Perbandingan antara jumlah penduduk dengan Jumlah Sampah di TPA

\begin{tabular}{|c|c|c|c|}
\hline \multirow[t]{2}{*}{ Kab/Kota } & \begin{tabular}{|l} 
Jumlah \\
Penduduk
\end{tabular} & $\begin{array}{lr}\text { Jumlah } & \text { Sampal } \\
\text { Ditimbun } & \text { TPA } \\
\text { (Ton/Hari) } & \end{array}$ & $\begin{array}{lr}\text { Jumlah } & \text { Sampah } \\
\text { yang } & \text { dihasilkan } \\
(\text { Kg/Jiwa }) & \end{array}$ \\
\hline & Th. 2017 & \begin{tabular}{|l|} 
Th. 2017-2018 \\
\end{tabular} & \begin{tabular}{|l|} 
Th. 2017 \\
\end{tabular} \\
\hline Bangka & 324,305 & 25,15 & 0,08 \\
\hline Belitung & 182,418 & 35,36 & 0,19 \\
\hline Bangka Barat & 204,778 & 8,26 & 0,04 \\
\hline Bangka Tengah & 188,603 & 13, & 0,07 \\
\hline Bangka Selatan & 201,782 & 11,5 & 0,06 \\
\hline Belitung Timur & 124,587 & 27,69 & 0.22 \\
\hline Pangkalpinang & 204,392 & 120 & 0,59 \\
\hline
\end{tabular}

Berdasarkan data tersebut di atas tampak bahwa jumlah penduduk yang besar tidak berarti jumlah sampah yang dihasilkan besar, sebagai contoh Kabupaten Bangka dengan jumlah penduduk 324.305 jiwa hanya menghasilkan $0,08 \mathrm{~kg} / \mathrm{jiwa}$ berbanding terbalik dengan Belitung Timur yang jumlah penduduknya 124.587 jiwa menghasilkan sampah sebesar 0,22 kg. Hal ini menandakan bahwa asumsi yang menyatakan bahwa dengan meningkatnya jumlah penduduk akan meningkatkan volume sampah seperti menurut Sulastri Tampuyak, Chairil Anwar dan Muh. Nur Sangadji (2016) 
tidak terbukti untuk kasus di kabupaten/kota di Provinsi Bangka Belitung.

\section{KESIMPULAN}

Dari hasil studi di atas didapat hasil semakin tingginya IPM berbanding lurus dengan banyaknya timbunan sampah di TPA. Dalam artian asumsi yang ada selama ini yang menganggap bahwa tingginya nilai IPM akan memperbaiki pengelolaan sampah untuk kasus ini ternyata kurang tepat.

Meningkatkanya jumlah sampah yang ditimbun di TPA dikarenakan meningkatnya jumlah sampah yang berasal dari lingkungan masyarakat. Nilai IPM yang tinggi menggambarkan 3 (tiga) dimensi dasar,yaitu : umur panjang dan hidup sehat, pengetahuan, serta standar hidup layak ternyata memberi pengaruh signifikan terhadap tingginya jumlah timbunansampah. Meningkatnya taraf hidup masyarakat menyebabkan tingkat konsumsi terhadap barangbarang yang mempunyai peluang untuk menjadi sampah meningkat. Untuk menekan tingginya timbunansampah masyarakat di TPA perlu kiranya memberikan edukasi kepada masyarakat untuk mengurangi pemakaian barangbarang yang akan menjadi sampah seperti plastik. Salah satu indikator IPM yang tinggi adalah meningkatnya Angka Harapan Lama Sekolah. Hal ini menunjukkan makin tingginya tingkat pendidikan masyarakat maka akan lebih mudah untuk diedukasi.

Asumsi yang menyatakan bahwa jumlah penduduk sangat mempengaruhi besaran jumlah timbunansampah yang ada di TPA ternyata untuk kabupaten/kota di Provinsi Kepulauan Bangka Belitung untuk sementara tidak terbukti. Hal ini dikarenakan ada daerah yang jumlah penduduknya sedikit tetapi jumlah sampah dari masyakarat lebih banyak daripada daerah yang jumlah penduduknya banyak.

Kajian ini masih memiliki ruang untuk dikaji dan dikembangkan lebih jauh dikarenakan kajian ini masih terbatas oleh data yang ada.

\section{DAFTAR PUSTAKA}

Badan Pusat Statistik Provinsi Kepulauan Bangka Belitung. https://babel.bps.go.id/subject/1 2/kependudukan.html\#subjekVie $w$ Tab3. diakses tanggal 13 Maret 2019.

Data Pengelolaan Sampah Nasional. http://sipsn.menlhk.go.id/. diakses tanggal 13 Maret 2019. Charisa Devi,Rifka. (2016). Hubungan Tingkat Pendidikan masyarakat dengan Prilaku Pengelolaan 
Sampah di Pemukiman Nelayan Kelurahan Bandengan Kecamatan Kota Tegal. Tugas Akhir Jurusan Geografi Fakultas Ilmu Sosial Universitas Negeri Semarang.

Harahap Rahmadani, Fitri. 2013. Dampak Urbanisasi Bagi Perkembangan Kota Di Indonesia. Jurnal Society, I(1), $35-45$.

Hoornweg, D. dan Bhada-Tata, P.2012. What A Waste A Global Review of Solid Waste Management, Washington, Urban Development \& Local Government Unit World Bank.

Junaidi. Regresi dengan Microsoft Excel.

https://repository.unja.ac.id/117/ 1/regresi\%20excel_junaidi2014. $p d f$. Diakses tanggal 13 Maret 2019.

Prajati,Gita., Padmi,Tri., dan Rahardyan ,Benno.2015. Pengaruh Faktor Faktor Ekonomi dan Kependudukan Terhadap
TimbunanSampah di Ibu Kota Provinsi Jawa dan Sumatera. Jurnal Teknik Lingkungan, 21(3), 39-47.

Puspita, Sherly. 19 Agustus 2018. Indonesia Penyumbang Plastik No. 2 di Dunia. https://megapolitan.kompas.com /read/2018/08/19/21151811/ind onesia-penyumbang-sampahplastik-terbesar-kedua-di-dunia. Diakses tanggal 14 Maret 2019.

S,Hardiatmi. 2011.Pendukung Keberhasilan Pengelolaan Sampah Kota. Innofarm. Jurnal Inovasi Pertanian, 10 (1), 50-66.

Tampuyak, Sulastri., Anwar, Chairil.,dan Sangadji, Muh. Nur. 2016. Analisis Proyeksi Pertumbuhan Penduduk dan Kebutuhan Fasilitas Persampahan Di kota Palu 20152025. Jurnal Universitas Tadulako, 4(3), 94-10 